\title{
Voluntary food intake and reproduction
}

By J. M. Forbes, Department of Animal Physiology and Nutrition, University of Leeds, Leeds LS2 $9 \mathfrak{F T}$

The underlying assumption I will make is that voluntary food intake is normally controlled so as to meet the requirements of the animal, especially for energy. This control is achieved by positive and negative feedbacks involving many pathways, in particular visceral receptors in communication with the central nervous system. Reproductive processes do not, on the whole, interfere seriously with this regulation and changes in nutrient demand, for example during lactation, are accompanied by the appropriate changes in voluntary intake. However, some of the changes which accompany reproductive processes have particular effects on intake which may have important implications, particularly in farm animals.

\section{Oestrus}

In female mammals there is often reduced voluntary intake at the time of oestrus, usually accompanied by restlessness and increased energy expenditure. Fig. I shows these changes of intake in the rat (Slonaker, I925), with increased intake during pregnancy, a fall at parturition, a further large rise as lactation proceeds and a steep fall at weaning. Note the low intakes when oestrus occurs in late lactation.

The cause of low food intake at oestrus is likely to be the elevated rate of secretion of oestrogens because treatment of ovariectomized females, or of males, with exogenous oestrogens to give similar plasma concentrations to those found at natural oestrus causes a similar depression in intake (see Hervey \& Hervey, 1981).

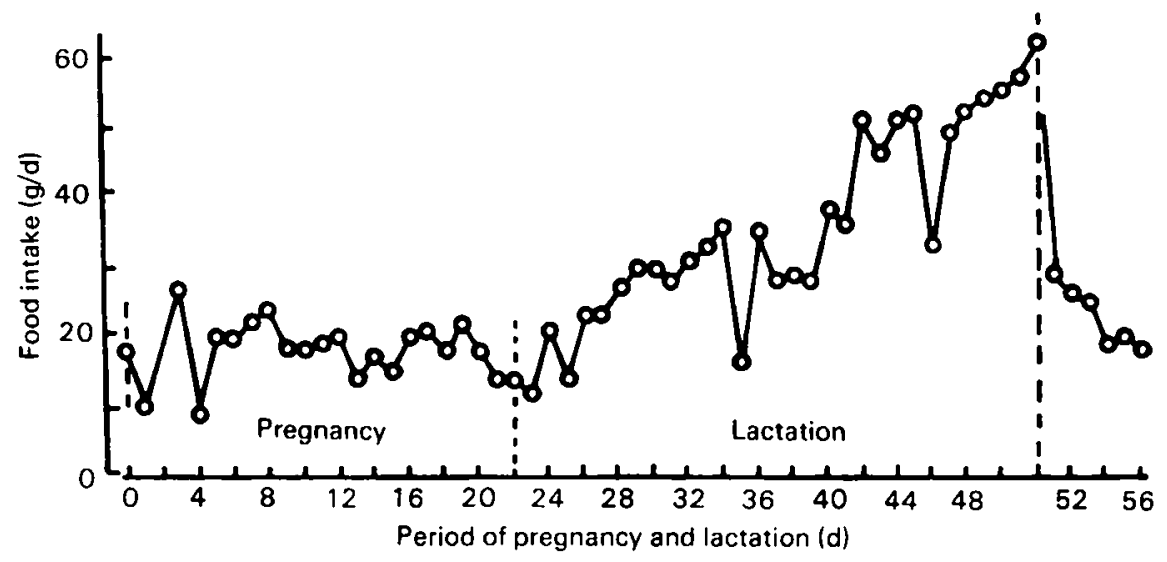

Fig. 1. Voluntary food intake of a female rat during pregnancy and lactation, including effects of oestrus during late lactation (from Slonaker, 1925). 
This effect is similar whether animals have had $10-15 \%$ of their body fat removed surgically (Gavin et al. 1984 ), are genetically obese (Dubuc, 1985 ) or are subjected to cellular glucoprivation by treatment with 2-deoxyglucose (McDermott $e t$ al. 1984). Lesions of the ventromedial hypothalamus (VMH) do not block the effect (King \& Cox, 1973) nor does hypophysectomy (Wade, 1974).

If intact females are treated with progesterone then oestrus cycles cease and intake stays at a high level; progesterone reverses the decrease in meal size and increase in meal frequency which are induced by oestradiol-benzoate treatment (Blaustein \& Wade, 1977).

During prolonged treatment with oestrogens, intake was at first depressed but returned to pre-treatment levels after about $20 \mathrm{~d}$ in one experiment (Tarttelin $\&$ Gorski, I97I) while remaining low for at least $32 \mathrm{~d}$ in another (Dubuc, 1985). The discrepancy between these observations has not so far been explained.

Wade \& Zucker (1970) showed that implantation of crystals of oestradiol benzoate in the VMH of rats depressed food intake and Stumpf (1970) found evidence for oestrogen receptors in several parts of the hypothalamus, including the VMH. These receptors in the VMH have been assumed to be the way in which oestrogens influence intake but Wade \& Gray (1979) have recently presented evidence for effects of oestrogens on the metabolism of liver, muscle and adipose tissue being involved in intake depression at oestrus. For example, oestrogen treatment has marked effects on liver metabolism (Matute \& Kalkhoff, 1973) and adipose tissue (Wade \& Gray, 1978), both tissues which are strongly implicated in the control of food intake. It is likely, therefore, that the effects of oestrogens on intake are mediated through several mechanisms.

There is a depression in intake in sows during oestrus (Friend, 1973) and also in cows (J. H. Metz, personal communication), ewes (Tarttelin. I968) and goats (Forbes, 1986a). The females of some species of primate tend to eat less during the follicular phase of the menstrual cycle, when the oestrogen:progesterone ratio in blood is higher than that during the luteal phase (Gilbert \& Gillman, 1956).

In ruminant species, treatment with exogenous oestrogens depresses food intake at doses which are equivalent, on a weight-for-weight basis, with the doses which have this effect in the rat. (Lower doses have growth-stimulating effects, with a small increase in intake.) In castrated male sheep continuous infusion of ${ }_{1}{ }_{7} \beta$-oestradiol into the jugular vein at $45-90 \mu \mathrm{g} / 24 \mathrm{~h}$ significantly depressed the intake of a concentrate feed (Forbes, 1971 ). Similarly, infusion of ${ }_{7} \beta$-oestradiol into female goats depressed intake of concentrates in a dose-related manner with rates of infusion ranging from 20 to $140 \mu \mathrm{g} / 24 \mathrm{~h}$. When a goat was in oestrus the effects on food intake both of oestrus and of exogenous oestrogen were additive (Forbes, 1986a; Fig. 2). In cows, oestradiol benzoate had an inhibitory effect on intake which was prevented by progesterone (Muir et al. 1972).

The site(s) of action of oestrogens in ruminant animals has not been the subject of much study, although injection into the lateral ventricles of the brain of castrated male sheep, at what were probably pharmacological levels (over $80 \mu \mathrm{g}$ ), did depress intake of a complete, pelleted feed (Forbes, 1974). 


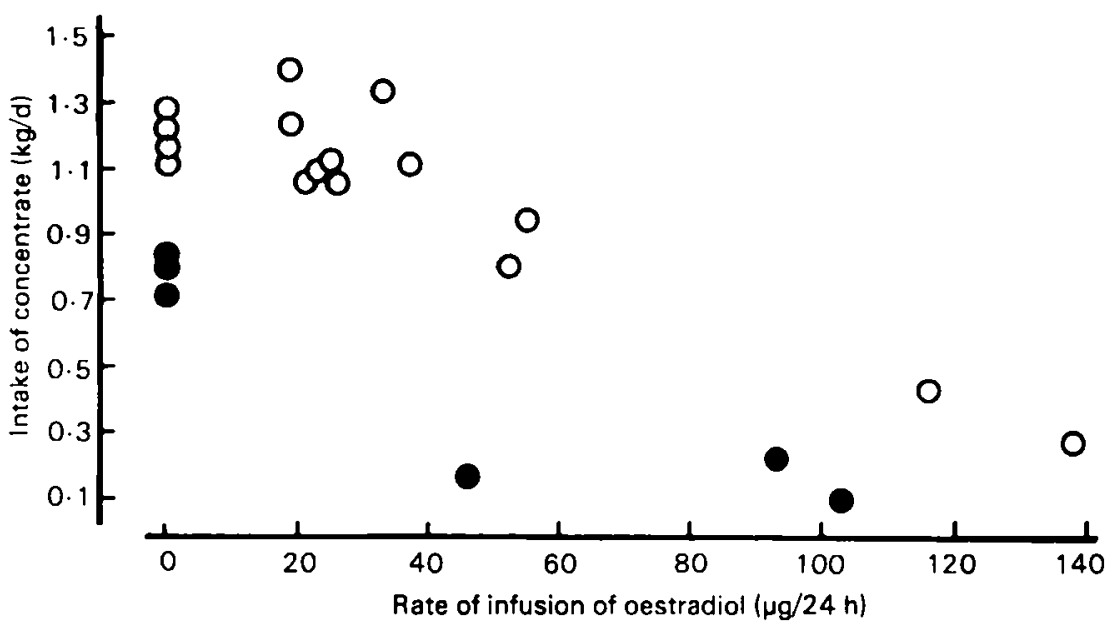

Fig. 2. The effects of continuous intravenous infusion of $17 \beta$-oestradiol on the intake of a concentrate feed by a female goat: $(O)$, Dioestrus; (O), oestrus (from Forbes, 1986a).

Women have more sensitive taste than men but the changes in preference that sometimes occur during the menstrual cycle and pregnancy may not be directly due to hormonal influences on feeding. In rats, sex hormones affect the choice of solutions with different tastes, with females showing higher preferences than males for saccharin and greater aversion to quinine (Zucker, 1969); treatment of ovariectomized females with oestrogen and a little progesterone restored these female preferences. There appear to be affects of sex hormones on dietary selection in ruminants as well, because oestrogens do not affect the intake of forage feeds as much as that of concentrates by castrated male sheep (Forbes, 1971). The goats referred to previously, which ate less concentrate when infused with oestradiol benzoate, did not eat less hay even though both were offered ad lib. (J. M. Forbes, unpublished results). J. H. Metz (personal communication) noted reduced concentrate intake on the day of oestrus in heifers but no change in hay intake. Both this apparent effect on choice of feed and the mode of action of oestrogens on the voluntary food intake of ruminants require further study.

\section{Pregnancy}

Several progressive changes occur during pregnancy so that it is sometimes difficult to determine the causes of observed changes in intake.

The requirements for nutrients increase steadily for the whole of pregnancy although they only become significant in relation to the requirements of the mother from about halfway through pregnancy. It is presumably this demand, especially for energy, that leads to the increase in voluntary intake which is usually seen in mid-pregnancy. Sheep and cattle do not show a large increase, perhaps simply because the conceptus is not proportionately as large as in species which produce large litters. Johnson et al. (1966) have claimed that 'suggestions of increased 
appetite accompanying pregnancy in dairy cattle are entirely unfounded' but small increases have been noted in ewes by Owen \& Ingleton ( 1963 ) and Forbes (1970a), and in heifers by Penzhorn \& Meintjes (1972). The way in which increased energy utilization stimulates intake is likely to be by more rapid removal of metabolites which cause satiety, rather than by a specific hormonal effect.

Pregnant rats allowed a choice of several foods decreased the proportion of carbohydrate eaten but increased their intake of protein and fat (Richter \& Barelare, 1938), whereas pregnant ewes do not show such nutritional wisdom (Gordon \& Tribe, I951).

A second way in which pregnancy might affect intake is that the growth of the pregnant uterus, although compensated for by increased girth, eventually competes with the digestive organs for space within the abdomen. In situations where the physical capacity of the stomachs is an important limit to intake, this competition will lead to a depression in intake; this is most likely to occur in ruminants but has also occurred in pregnant mice when the food was diluted excessively with inert material (Forbes, 1968a). It has been demonstrated many times that reduction of rumen capacity by inflation of a balloon within the rumen causes reduced intake of slowly digested, forage feeds (e.g. Campling $\& \mathrm{Balch}$, I961). A positive relation has also been seen between the volume of rumen contents and the level of roughage intake (e.g., Tayler, I959). It is tempting to suggest, therefore, that the reduction in the volume of rumen contents that occurs in late pregnancy, both in sheep (see below) and in cattle (Makela, 1956), is a result of compression and causes in turn the reduction in voluntary food intake which is often observed at that time. By slaughtering ewes at various stages of pregnancy, Forbes $(1968 b)$ showed a negative relation between the volume of 'incompressible' abdominal contents and the volume of digesta in the rumen, also a positive correlation of this volume of digesta and the level of intake of hay during the 2 weeks before slaughter (Forbes, 1969). It might be, however, that the reduction in rumen contents is the result (rather than the cause) of the lower level of intake. If this were the case then one would expect a reduction in the rate of passage of food particles as pregnancy progressed. In fact the rate of passage accelerates (Graham \& Williams, I962; Forbes, 1968a), which supports the case for an important role for rumen compression as a contributory cause of the observed reduction in intake which often occurs in ruminants during the last few weeks of pregnancy (see Forbes, 1970b).

There is another change taking place in late pregnancy which probably contributes to the decline in intake: the placental production of oestrogens has increased by the last few weeks to rates at least as great as those which depress intake when administered to non-pregnant animals (see p. 194). Although it might be thought from the work of Muir et al. (1972) and Bargeloh et al. (1975) that the high rate of secretion of progesterone would protect from the effects of oestrogens, infusion of $17 \beta$-oestradiol at rates similar to those at which oestrogens are produced in late pregnancy was still effective in depressing the intake of concentrates by castrated male sheep when accompanied by progesterone oat 5 
$\mathrm{mg} / 24 \mathrm{~h}$, a rate similar to that from the placenta in late pregnancy. The potential exists, therefore, for oestrogens to inhibit food intake in ruminants in late pregnancy. Over the last 2 or $3 \mathrm{~d}$ before parturition there is a great spurt in oestrogen secretion in the ewe (Challis, 1971) which probably accounts for the drastic reduction in intake at that time, although the discomfort of approaching parturition must also play a part.

Another factor contributing to the decline of food intake in late pregnancy might be marginal protein deficiency if dietary protein content remains constant as the requirements of the mother increase with the growth of the fetuses. Protein deficiency can inhibit food intake in any species; in the ruminant both the host animal and its symbiotic rumen micro-organisms need to be supplied with adequate protein and non-protein-nitrogen respectively.

With these various possible ways in which intake can be stimulated and inhibited at various stages of pregnancy, there is no simple qualitative hypothesis that can be stated to explain the pattern of food intake observed under a particular set of circumstances. In an attempt to integrate the various factors in a quantitative manner, Forbes (1977a) used relations between metabolizable energy requirements, physical competition for abdominal space and voluntary intake to develop a simple mathematical model to simulate energetic and physical relations in the pregnant ewe on a daily basis. Fig. 3 shows the predictions for ewes producing single or twin lambs offered a feed with a dry matter digestibility of 0.65 . In this case intake is taken to be limited either by metabolic requirements (as in early pregnancy and after weaning) or by physical limitation (as in late pregnancy and during lactation). Further consideration of the interactions between

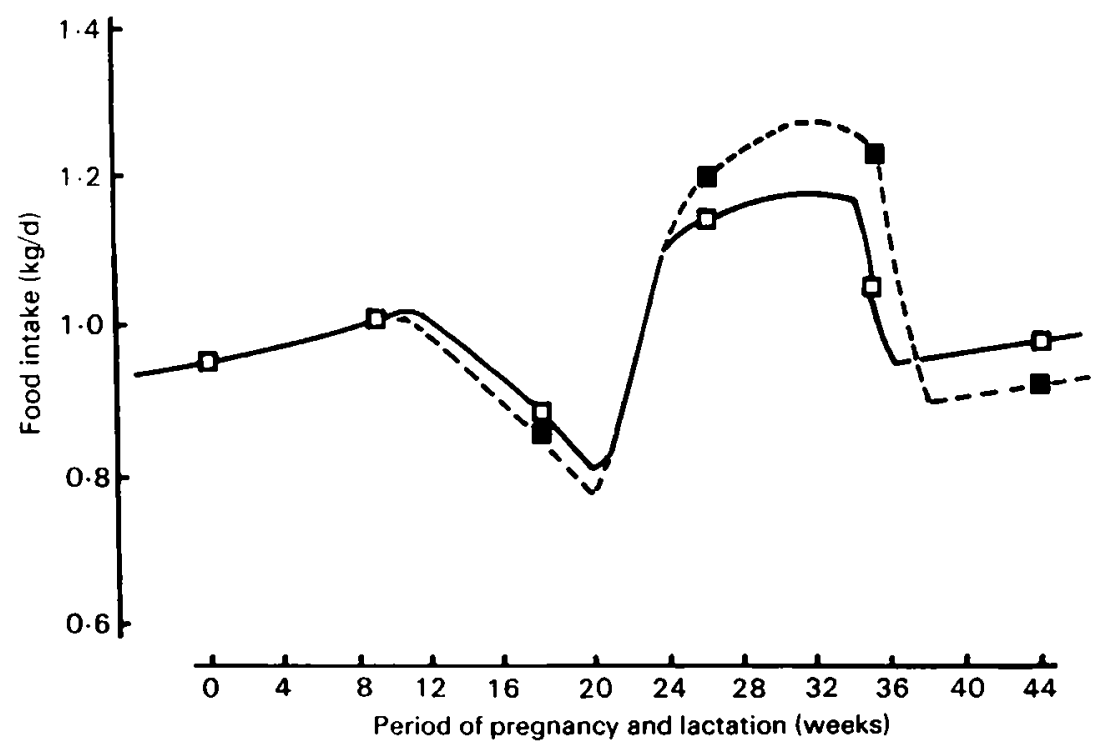

Fig. 3. Predictions of a mathematical model designed to simulate the changes in voluntary food intake of ewes during pregnancy (0-20 weeks) and lactation (20-36 weeks): ( $\square$ ), with a single lamb; (ם), with twin lambs (from Forbes, 1977a). 
the various feedback signals involved in the control of intake suggest that there is no such clear-cut differentiation but rather that physical and metabolic signals have additive effects (see Forbes, $1986 b$ ).

In a more detailed model which incorporated minute-by-minute changes in the rates of absorption and utilization of energy, and the accumulation and passage of bulk in the stomachs of the sheep (Forbes, 1980 ), pregnancy was again simulated by a gradual increase in energy requirements with a gradual reduction in rumen capacity. The model, which gave predictions of meal size and frequency, suggested a decrease in meal size and increase in meal frequency as pregnancy progressed. As no information existed with which to compare these predictions we have monitored the feeding behaviour of four ewes from midpregnancy (R. Jones, F. F. Bermudez and J. M. Forbes, unpublished results) and found increasing numbers of smaller meals as predicted by the model.

\section{Lactation}

Voluntary intake increases rapidly in early lactation in most species and matches the increased energy requirements of lactation. In the rat the intake of the dam is positively related to the number of young being suckled and falls quite abruptly at weaning (e.g. Slonaker, 1925; Fig. I). Levels of feeding during pregnancy also affect intake during lactation and Salmon-Legagneur \& Rerat (1962) found that sows which had been restricted to half of the $a d$ lib. level during pregnancy ate significantly more during lactation than sows fed $a d$ lib. throughout.

In sheep and cattle the increase in intake during early lactation often fails to keep pace with the increase in energy expenditure, especially in animals with high milk yields, and a mobilization of body reserves usually occurs. Not only is the cycle of mobilization and replenishment of reserves inefficient in terms of energy utilization, it also makes it more difficult to get the cow pregnant again if she is losing weight at the time of insemination and embryo development. The rate of increase of intake in early lactation in cows is affected by body fatness, cows made moderately fat by overfeeding during late pregnancy reaching peak intake at a later point in lactation than thinner cows (Garnsworthy \& Topps, 1982); it is also affected by the quality of the feed, with high-forage diets leading to slower rates of increase than feeds high in concentrates (Ronning \& Laben, 1966).

As milk yield falls from the peak, intake usually stays high and body reserves are gradually replaced. Treating lactating cows with growth hormone prolongs the peak of lactation and voluntary intake remains at a high level in response to the increase in nutrient requirements, compared with untreated cows (Bauman et al. I985).

The interrelations between the various factors affecting intake during lactation in ruminants are as complex as those in pregnancy and are thus a suitable subject for simulation modelling. In the day-by-day sheep model (Forbes, 1977a; Fig. 3), intake was limited throughout lactation by physical limitations and was higher in ewes rearing twins only because of reduced abdominal fat. This and later models 
(Forbes, $1977 b, 1980,1983$ ), which also assumed that intake was limited either by physical or metabolic factors, should be modified to incorporate the concept of additivity of signals affecting intake (Forbes, 1986b).

\section{Oviposition}

Hens eat more on days in which eggs are being formed than on non-egg-forming days (e.g. Bordas \& Merat, 1976) and mean egg production is positively correlated with voluntary intake over a long period of time (Ivy \& Gleaves, 1976). Feeding activity is depressed for several hours before an egg is layed and there is increased intake of a calcium-supplying supplement around the time the shell is being deposited (Mongin \& Sauveur, 1979).

Although pullets eat less in total around puberty they select for $\mathrm{Ca}$ at this time (Meyer et al. 1970). The increases in intake of $\mathrm{Ca}$ which occur around puberty and during shell formation are probably due to increased oestrogen secretion at these times as treatment of cockerels with oestradiol causes increased $\mathrm{Ca}$ intake (see Mongin \& Sauveur, 1979).

\section{Male reproduction}

The male of most species becomes excited when exposed to females in oestrus and is distracted from feeding. If such exposure is frequent or protracted then daily food intake might be depressed.

Several ruminant species show a seasonal rhythm of intake which is entrained by photoperiod (Forbes, 1982), intake being positively related to photoperiod. The stag exhibits a marked seasonal inappetence around the onset of oestrous cycling of the hind in early autumn, the rut. During this period stags eat very little and lose a lot of weight. Depressed intake occurs even when stags are kept in pens well away from females and there is also seasonal inappetence in female and castrated male deer, though the amplitude is less than that in intact stags (Kay, 1979).

\section{Conclusion}

Although most animals maintain food intake at an appropriate level to maintain body condition during reproductive cycles, both oestrus and annual, there are periods within each cycle when intake is low and body stores are mobilized; compensatory hyperphagia usually follows such periods. At oestrus and in late pregnancy there are declines in food intake which are due to high rates of oestrogen secretion, with receptor site(s) in the hypothalamus or peripheral tissues, or both, being involved. In ruminant animals, where physical limitations to intake are often important, the decline in intake that is often seen in late pregnancy can also be attributed to competition with the growing uterus for abdominal space. The slow increase in intake often seen in cows and ewes during early lactation cannot easily be explained by this competition, however, and further understanding is sought, through, for example, the medium of simulation modelling. 


\section{REFERENCES}

Bargeloh, J. F., Hibbs, J. W. \& Conrad, H. R. (1975). Fournal of Dairy Science 58, I 701-1 707.

Bauman, D. E., Eppard, P. J., DeGeeter, M. J. \& Lanza, G. M. (1985). Fournal of Dairy Science 68, $1352-1362$.

Blaustein, J. D. \& Wade, G. N. (1977). Physiology and Behavior 19, 23-27.

Bordas, A. \& Merat, P. (1976). British Poultry Science 17, 415-426.

Campling, R. C. \& Balch, C. C. (1961). British fournal of Nutrition 15, 523-530.

Challis, J. R. G. (1971). Nature 229, 208.

Dubuc, P. U. (1985). Proceedings of the Society for Experimental Biology and Medicine 180, 468-473.

Forbes, J. M. (1968a). The effect of pregnancy on rumen volume and voluntary feed intake in the ewe. $\mathrm{PhD}$ Thesis, L'niversity of Leeds.

Forbes, J. M. (1 968b). Fournal of Agricultural Science, Cambridge 70, $171-177$.

Forbes, J. M. (1 969). Yournal of Agricultural Science, Cambridge 72, I 19-1 2 I.

Forbes, J. M. (1970a). Fournal of Animal Science 31, 1 222-1 227.

Forbes, J. M. (1970b). British Veterinary fournal 126, 1-1 1.

Forbes, J. M. (1 971). Fournal of Endocrinology 52, viii-ix.

Forbes, J. M. (1974). Physiology and Behavior 12, 74 1-747.

Forbes, J. M. (1977a). Animal Production 24, 90-101.

Forbes, J. M. (1977b). Animal Production 24, 203-214.

Forbes, J. M. (1980). Appetite 1, 21-41.

Forbes, J. M. (1982). Livestock Production Science 9, 361-374.

Forbes, J. M. (1983). Livestock Production Science 10, $149-157$.

Forbes, J. M. (1986a). In Control of Digestion and Metabolism in the Ruminant, pp. 420-435 [L. P. Milligan, W. L. Grovum and A. Dobson, editors]. Englewood Cliffs, New Jersey: Prentice-Hall.

Forbes, J. M. (1986b). The Voluntary Food Intake of Farm Animals. London: Butterworths.

Friend, D. W. (1973). Fournal of Animal Science 37, $1137-1141$.

Garnsworthy, P. C. \& Topps, J. H. (1982). Animal Production 35, II 3-1 I 9.

Gavin, M. L., Gray, J. M. \& Johnson, P. R. (1984). Physiology and Behavior 32, 55-60.

Gilbert, C. \& Gillman, J. (1956). South African Yournal of Medical Science 21, 75-78.

Gordon, J. G. \& Tribe, D. E. (1951). Fournal of Agricultural Science, Cambridge 41, I87-190.

Graham, N. M. \& Williams, A. J. (1962). Australian Fournal of Agricultural Research I3, $894-900$.

Hervey, E. \& Hervey, G. R. (1981). In The Body Weight Regulatory System: Normal and Disturbed Mechanisms, pp. $345^{-352}$ [L. A. Cioff, W. P. T. James and T. B. van Itallie, editors]. New York: Raven Press.

Ivy, R. E. \& Gleaves, E. W. (1976). Poultry Science 55, 2166-2171.

Johnson, W. L., Trimberger, G. W., Wright, M. J., Van Vleck, L. D. \& Henderson, C. R. (1966). Journal of Dairy Science 49, 856-864.

Kay, R. N. B. (1979). Agricultural Research Council Research Reviews 5, 13-1 5.

King, J. M. \& Cox, V. C. (1 973). Physiological Psychology I, 26 I-264.

McDermott, L. J., Jorgensen, D. E. \& Byers, D. J. (1984). Physiology and Behavior 32, 731-736.

Makela, A. (1956). Annals of Agricultural Science, Fennica 85, 1-130.

Matute, M. L. \& Kalkhoff, R. K. (1973). Endocrinology 92, $762-768$.

Meyer, G. B., Babcock, S. W. \& Sunde, M. L. (1970). Poultry Science 49, $1164-1169$.

Mongin, P. \& Sauveur, B. (1979). In Food Intake Regulation in Poultry, pp. 171-189 [K. N. Boorman and B. M. Freeman, editors]. Edinburgh: British Poultry Science Ltd.

Muir, L. A., Hibbs, J. W., Conrad, H. R. \& Smith, K. L. (1972). Fournal of Dairy Science 55, $1613-1620$.

Owen, J. B. \& Ingleton, J. W. (1963). Journal of Agricultural Science, Cambridge 6r, 329-340.

Penzhorn, E. J. \& Meintjes, J. P. (1972). Agroanimalia 4, 83-92.

Richter, C. P. \& Barelare, B. (1938). Endocrinology 23, $15-24$.

Ronning, M. \& Laben, R. C. (1966). Fournal of Dairy Science 49, $1080-1085$.

Salmon-Legagneur, E. \& Rerat, A. (1962). In Nutrition of Pigs and Poultry, pp. 207-223 [J. J. Morgan and D. Lewis, editors]. London: Butterworths. 
Slonaker, J. R. (1925). American fournal of Physiology 71, 362-394.

Stumpf, W. E. (1970). American Yournal of Anatomy 1 29, 207-2 18.

Tartelin, M. F. (1968). Fournal of Physiology 195, $29 \mathrm{P}-31 \mathrm{P}$.

Tarttelin, M. F. \& Gorski, R. A. (1971). Federation Proceedings 30, 253.

Tayler, J. C. (1959). Nature 184, 202 I-2022.

Wade, G. N. (1974). Yournal of Comparative and Physiological Psychology 86, 359-362.

Wade, G. N. \& Gray, J. M. (1978). Endocrinology 103, I695-1 701.

Wade, G. N. \& Gray, J. M. (1979). Physiology and Behavior 22, 583-593.

Wade, G. N. \& Zucker, I. (1970). Fournal of Comparative Physiology and Psychology 72, $328-336$.

Zucker, 1. (1969). Physiology and Behavior 4, 595-602. 